\title{
Biomagnification of Mercury in Aquatic Food Webs: A Worldwide Meta-Analysis
}

Raphael A. Lavoie, ${ }^{\dagger} *$ Timothy D. Jardine, ${ }^{\ddagger}$ Matthew M. Chumchal, ${ }^{\S}$ Karen A. Kidd," and Linda M. Campbell ${ }^{\dagger, \perp}$

${ }^{\dagger}$ Biology Department, Queen’s University, 116 Barrie Street, Kingston, Ontario, K7L 3N6, Canada

${ }^{\ddagger}$ Toxicology Centre and School of Environment and Sustainability, University of Saskatchewan, 44 Campus Drive, Saskatoon, Saskatchewan, S7N 5B3, Canada

${ }^{\S}$ Department of Biology, Texas Christian University, P.O. Box 298930, Fort Worth, Texas, 76129, United States

"Canadian Rivers Institute \& Biology Department, University of New Brunswick, 100 Tucker Park Road, Saint John, New Brunswick, E2L 4L5, Canada

${ }^{\perp}$ Environmental Science, Saint Mary’s University, 923 Robie Street, Halifax, Nova Scotia, B3H 3C3, Canada

Supporting Information

ABSTRACT: The slope of the simple linear regression between $\log _{10}$ transformed mercury $(\mathrm{Hg})$ concentration and stable nitrogen isotope values $\left(\delta^{15} \mathrm{~N}\right)$, hereafter called trophic magnification slope (TMS), from several trophic levels in a food web can represent the overall degree of $\mathrm{Hg}$ biomagnification. We compiled data from 69 studies that determined total $\mathrm{Hg}(\mathrm{THg})$ or methyl $\mathrm{Hg}(\mathrm{MeHg})$ TMS values in 205 aquatic food webs worldwide. Hg TMS values were compared against physicochemical and biological factors hypothesized to affect $\mathrm{Hg}$ biomagnification in aquatic systems. Food webs ranged across $1.7 \pm$ $0.7($ mean $\pm \mathrm{SD})$ and $1.8 \pm 0.8$ trophic levels (calculated using $\delta^{15} \mathrm{~N}$ from baseline to top predator) for $\mathrm{THg}$ and $\mathrm{MeHg}$, respectively. The average trophic level (based on $\delta^{15} \mathrm{~N}$ ) of the upper-trophic-level organisms in the food web was $3.7 \pm 0.8$ and $3.8 \pm 0.8$ for $\mathrm{THg}$ and

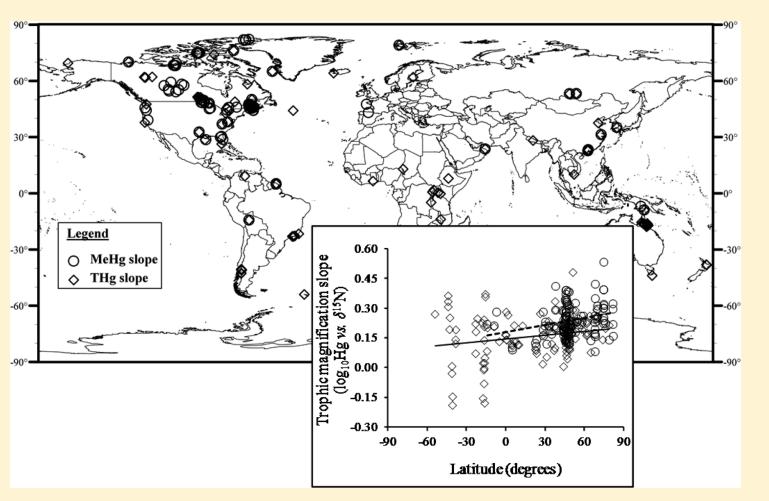
$\mathrm{MeHg}$ food webs, respectively. For MeHg, the mean TMS value was $0.24 \pm 0.08$ but varied from 0.08 to 0.53 and was, on average, 1.5 times higher than that for THg with a mean of $0.16 \pm 0.11$ (range: -0.19 to 0.48 ). Both $\mathrm{THg}$ and $\mathrm{MeHg} \mathrm{TMS}$ values were significantly and positively correlated with latitude. TMS values in freshwater sites increased with dissolved organic carbon and decreased with total phosphorus and atmospheric $\mathrm{Hg}$ deposition. Results suggest that $\mathrm{Hg}$ biomagnification through food webs is highest in cold and low productivity systems; however, much of the among-system variability in TMS values remains unexplained. We identify critical data gaps and provide recommendations for future studies that would improve our understanding of global $\mathrm{Hg}$ biomagnification.

\section{INTRODUCTION}

Humans have altered the natural biogeochemical cycling of the toxic metal mercury $(\mathrm{Hg})$, with coal combustion and gold mining accounting for the majority of atmospheric emissions over the past 150 years. ${ }^{1}$ The bulk of contemporary $\mathrm{Hg}$ emissions are currently re-emitted legacy anthropogenic emissions. ${ }^{2}$ Mercury contamination is a global issue due to its long-distance transport ${ }^{3}$ and potential toxicity. ${ }^{4}$ Of particular concern is methylmercury ( $\mathrm{MeHg}$ ), which can be converted from inorganic forms of mercury in aquatic ecosystems. Efficient trophic transfer of $\mathrm{MeHg}$ through aquatic food webs (i.e., biomagnification) results in $\mathrm{Hg}$ concentrations in predator species which can be millions of times higher than those observed in surface waters. ${ }^{5}$ Biomagnification of $\mathrm{Hg}$ has been consistently observed in freshwater and marine food webs ${ }^{6-9}$ and can lead to toxic concentrations in fish and fish-eating wildlife. ${ }^{10}$
Stable nitrogen isotopes $\left(\delta^{15} \mathrm{~N}\right)$ are used to characterize trophic relationships in aquatic food webs. ${ }^{11,12}$ Increasing $\delta^{15} \mathrm{~N}$ values typically indicate increasing trophic position within a food web as most organisms consistently excrete lighter nitrogen isotopes $\left({ }^{14} \mathrm{~N}\right)$ and retain heavier isotopes $\left({ }^{15} \mathrm{~N}\right)$, which results in increasing tissue ratios of ${ }^{15} \mathrm{~N} /{ }^{14} \mathrm{~N}$ through the food web. Since $\mathrm{THg}$ and $\mathrm{MeHg}$ tend to biomagnify in ecosystems, the simple linear relationship between $\mathrm{Hg}$ and $\delta^{15} \mathrm{~N}$ values in organisms within a food web can be used to quantify the degree of biomagnification (i.e., the average change in tissue $\mathrm{Hg}$ concentration with trophic position). Biomagnification of $\mathrm{Hg}$ is typically calculated by using the following equation:

Received: July 13, 2013

Revised: October 15, 2013

Accepted: October 23, 2013

Published: October 23, 2013 
Table 1. Summary of Factors Known to Affect Hg Bioaccumulation, Hypotheses about Their Effects on Trophic Magnification Slopes (TMS), and Predicted and Observed Relationships with THg and MeHg Trophic Magnification Slopes (TMS) in Freshwater Sites $^{a}$

\begin{tabular}{|c|c|c|c|c|c|}
\hline \multirow[t]{2}{*}{ controller } & \multirow[t]{2}{*}{ hypothesis } & \multirow[t]{2}{*}{$\begin{array}{c}\text { measured } \\
\text { variable }\end{array}$} & \multirow[t]{2}{*}{$\begin{array}{l}\text { predicted } \\
\text { outcome }\end{array}$} & \multicolumn{2}{|c|}{ outcome $^{b}$} \\
\hline & & & & $\mathrm{THg}$ & $\mathrm{MeHg}$ \\
\hline acidity & greater $\mathrm{Hg}$ bioavailability in acidic waters; ${ }^{10,77}$ slower growth of biota in acidic waters. ${ }^{10}$ & $\mathrm{pH}^{c}$ & - & $\mathrm{ns} / \mathrm{ns}$ & ns/+ \\
\hline $\begin{array}{l}\text { dissolved } \\
\text { organic } \\
\text { carbon } \\
\text { (DOC) }\end{array}$ & $\begin{array}{l}\text { higher } \mathrm{Hg} \text { concentrations in higher DOC waters under wetland influence } \\
\text { bioavailability, }{ }^{58} \text { reduced trophic transfer }{ }^{58,70} \text { and enhancement of demethylation }{ }^{77}(-) \text {. }\end{array}$ & $\begin{array}{l}\text { DOC }^{c} \\
\% \text { wetland }^{c}\end{array}$ & $\begin{array}{c}+ \text { and }- \\
+\end{array}$ & $\begin{array}{c}+/ \mathrm{ns} \\
\mathrm{ns} /\end{array}$ & $\begin{array}{c}\mathrm{ns} /+ \\
\mathrm{ns} /\end{array}$ \\
\hline \multirow[t]{4}{*}{ Hg availability } & \multirow{4}{*}{$\begin{array}{l}\text { greater dissolved uptake of } \mathrm{Hg} \text { lower in the food web and reduced biomagnification when } \\
\text { dietary concentrations are high. }{ }^{17-19} \text { intracellular competitive uptake kinetics and regulation } \\
\text { mechanisms. }\end{array}$} & $\mathrm{Hg}$ in water ${ }^{c}$ & - & $\mathrm{ns} / \mathrm{ns}$ & $-/ \mathrm{ns}$ \\
\hline & & $\mathrm{Hg}$ in sediments ${ }^{c}$ & - & ns/ & ns/ \\
\hline & & $\mathrm{Hg}$ deposition ${ }^{d}$ & - & $\mathrm{ns} /-$ & $-/-$ \\
\hline & & $\mathrm{Hg}_{\text {baseline }}{ }^{e}$ & - & $\mathrm{ns} / \mathrm{ns}$ & $\mathrm{ns} /-$ \\
\hline \multirow{7}{*}{$\begin{array}{l}\text { growth/ } \\
\text { productivity }\end{array}$} & \multirow{7}{*}{$\begin{array}{l}\text { rapid growth causes dilution of } \mathrm{Hg} \text { in body tissues. }{ }^{71} \text { high productivity causes biomass dilution } \\
\text { of } \mathrm{Hg} .\end{array}$} & latitude ${ }^{c}$ & + & +1 & +1 \\
\hline & & chlorophyll- $a^{c}$ & - & +1 & -1 \\
\hline & & total phosphorus ${ }^{c}$ & - & $\mathrm{ns} /-$ & $\mathrm{ns} /-$ \\
\hline & & total nitrogen ${ }^{c}$ & - & ns/ & ns/ \\
\hline & & $\begin{array}{l}\text { productivity } \\
\text { status }^{e}\end{array}$ & - & ns/ & ns/ \\
\hline & & $\begin{array}{l}\text { phosphorus } \\
\text { loading }\end{array}$ & - & $+/+$ & $-/-$ \\
\hline & & $\begin{array}{l}\text { lake and } \\
\text { watershed area }^{c}\end{array}$ & + & ns/ & ns/ \\
\hline \multirow[t]{2}{*}{$\begin{array}{l}\text { energy } \\
\text { efficiency }\end{array}$} & \multirow[t]{2}{*}{$\begin{array}{l}\mathrm{Hg} \text { is retained more readily than biomass; top predator endotherms magnify } \mathrm{Hg} \text { more } \\
\text { readily. }\end{array}$} & $\begin{array}{l}\text { species } \\
\text { composition }^{c}\end{array}$ & + & ns/ & ns/ \\
\hline & & $\%$ of endotherms ${ }^{e}$ & + & $\mathrm{ns} /$ & ns/ \\
\hline
\end{tabular}

${ }^{a}$ TMS values represent individual slopes $(b)$ of simple linear regressions between $\log _{10}[\mathrm{Hg}]$ and $\delta^{15} \mathrm{~N}$ for several sites worldwide. ${ }^{b} \mathrm{Not}$ significant (ns). Results of multiple statistical tests are separated by a slash (regression or correlation/multiple linear regression). ${ }^{c}$ Extracted from reviewed or parallel studies (in situ physico-chemistry). ${ }^{d}$ Extracted by GIS (in silico physico-chemistry). ${ }^{e}$ Calculated from food web values provided in reviewed studies (see Methods for calculations).

$$
\log _{10}[\mathrm{Hg}]=\delta^{15} \mathrm{~N}(b)+a
$$

where the slope $(b)$ of this regression, hereafter called the Trophic Magnification Slope (TMS), has been routinely used as an indicator of biomagnifying potential of $\mathrm{Hg}$ in food webs since the early $1990 \mathrm{~s}^{13}$ (see also Supporting Information, SI, Table $\mathrm{S} 1$ ). A significant and positive slope (TMS >0) indicates $\mathrm{Hg}$ biomagnification in a food web. This approach has been widely applied to assess $\mathrm{Hg}$ biomagnification worldwide (SI Table S1).

It is well established that the concentrations of $\mathrm{Hg}$ in fish and invertebrates are positively related to atmospheric $\mathrm{Hg}$ deposition, ${ }^{14,15}$ but $\mathrm{Hg}$ concentrations in biota are also influenced by the intrinsic physical and chemical characteristics of a given ecosystem since they play an important role in $\mathrm{Hg}$ bioavailability at the water/primary production interface. For example, low $\mathrm{pH}$, elevated dissolved organic carbon (DOC) and high aqueous $\mathrm{Hg}$ concentrations are typically associated with high concentrations of $\mathrm{Hg}$ in invertebrates and fish. ${ }^{10,14,16}$ However, the influence of these variables on $\mathrm{Hg}$ biomagnification in food webs is unclear. It is especially unknown if biomagnification is only affected by food web processes (e.g., growth rate, species diversity and length of the food chain) or if physico-chemistry variables are also modulating $\mathrm{Hg}$ biomagnification. For example, elevated concentrations of $\mathrm{MeHg}$ in prey may in fact reduce the transfer of $\mathrm{Hg}$ to predators ${ }^{17-19}$ (e.g., by intracellular competitive uptake kinetics and regulation mechanisms ${ }^{20-22}$ ). Moreover, ecosystem characteristics and food web processes may interact to influence Hg TMS: low productivity, acidic $\mathrm{pH}$ and cold temperatures could indirectly increase $\mathrm{Hg}$ TMS by reducing feeding and growth efficiency ${ }^{23}$ and lowering excretion rates of $\mathrm{MeHg}$ in biota. ${ }^{24}$ In addition, higher nutrient concentrations may reduce $\mathrm{MeHg}$ at the base of the food $\mathrm{web}^{25}$ and can lead to dilution of $\mathrm{Hg}$ in upper-trophic-level consumers. ${ }^{26-28}$ These effects lead to the prediction that ecosystems in equatorial regions, where temperature, primary productivity and growth rates are high$\mathrm{er}^{29,30}$ and food webs are generally shorter, ${ }^{31}$ may exhibit lower $\mathrm{Hg}$ TMS compared to those in temperate or polar regions. ${ }^{32}$

Several authors have noted that TMS values often fall within a similar range; however, among-system differences in Hg TMS values occur for reasons that are not yet well understood. ${ }^{5}$ In this study, we compiled and queried a global database of the large and growing body of literature on $\mathrm{Hg}$ biomagnification to quantify average $\mathrm{Hg}$ TMS values (slope $(b)$ in eq 1 ) from freshwater and marine ecosystems. Our objective was to test hypotheses related to physico-chemistry (e.g., productivity and acidification) as well as food web processes (e.g., growth rate and species composition) that are thought to explain variation in $\mathrm{Hg}$ biomagnification (rather than $\mathrm{Hg}$ concentration) among ecosystems on a global scale (see Table 1 for a list of hypotheses). We also identified critical data gaps, and methodology and conceptual issues in the literature and provided recommendations for future biomagnification studies that could contribute to our understanding of $\mathrm{Hg}$ biomagnification.

\section{MATERIALS AND METHODS}

Mercury Biomagnification and Trophic Magnification Factor. In our meta-analysis, the variable of interest was the TMS value, which is the slope $(b)$ of the relationship between logarithm transformed (to the base 10) $\mathrm{Hg}$ concentration ( $\mathrm{THg}$ or $\mathrm{MeHg}$ ) and $\delta^{15} \mathrm{~N}$ values of biota from several trophic levels 
Table 2. Trophic Magnification Slopes (TMS Values, Mean \pm SD, $n$ ) Based on Wet Weight for All Sites Reviewed in This Study ${ }^{a}$

\begin{tabular}{|c|c|c|c|c|c|c|c|c|c|c|}
\hline & \multicolumn{4}{|c|}{$\mathrm{THg}^{b}$} & & \multicolumn{5}{|c|}{$\mathrm{MeHg}^{b}$} \\
\hline & mean & \pm & $\mathrm{SD}$ & $n$ & & mean & \pm & $\mathrm{SD}$ & $n$ & \\
\hline \multicolumn{11}{|l|}{ freshwater only } \\
\hline \multicolumn{11}{|l|}{ latitudinal classes } \\
\hline polar & 0.19 & & & 1 & & 0.28 & \pm & 0.09 & 24 & $a$ \\
\hline temperate & 0.16 & \pm & 0.10 & 65 & & 0.24 & \pm & 0.07 & 78 & $a$ \\
\hline tropical & 0.12 & \pm & 0.12 & 35 & & 0.16 & \pm & 0.07 & 8 & $b$ \\
\hline \multicolumn{11}{|l|}{ species composition } \\
\hline fish only & 0.16 & \pm & 0.13 & 30 & & 0.28 & & & 1 & \\
\hline fish and other species ${ }^{c}$ & 0.14 & \pm & 0.09 & 68 & & 0.24 & \pm & 0.08 & 106 & \\
\hline other species, no fish ${ }^{c}$ & 0.19 & \pm & 0.10 & 3 & & 0.31 & \pm & 0.10 & 3 & \\
\hline \multicolumn{11}{|c|}{ productivity status based on in situ phosphorus } \\
\hline hypereutrophic & 0.17 & \pm & 0.08 & 4 & & 0.16 & \pm & 0.05 & 3 & \\
\hline eutrophic & 0.22 & \pm & 0.09 & 9 & & 0.26 & \pm & 0.06 & 8 & \\
\hline mesotrophic & 0.14 & \pm & 0.09 & 11 & & 0.24 & \pm & 0.06 & 19 & \\
\hline oligotrophic & 0.13 & \pm & 0.12 & 33 & & 0.24 & \pm & 0.07 & 35 & \\
\hline \multicolumn{11}{|l|}{ type of ecosystem } \\
\hline lentic & 0.16 & \pm & 0.10 & 60 & $a$ & 0.23 & \pm & 0.08 & 77 & $b$ \\
\hline lotic & 0.12 & \pm & 0.11 & 41 & $b$ & 0.27 & \pm & 0.08 & 33 & $a$ \\
\hline total for freshwater sites & 0.15 & \pm & 0.11 & 101 & $\mathbf{B} / \mathbf{b}$ & 0.24 & \pm & 0.08 & 110 & $\mathbf{A} / \mathbf{a}$ \\
\hline \multicolumn{11}{|l|}{ marine } \\
\hline \multicolumn{11}{|l|}{ latitudinal classes } \\
\hline polar & 0.21 & \pm & 0.07 & 8 & & 0.21 & \pm & 0.09 & 7 & \\
\hline temperate & 0.22 & \pm & 0.11 & 13 & & 0.26 & \pm & 0.08 & 6 & \\
\hline tropical & 0.16 & \pm & 0.08 & 5 & & 0.14 & & & 1 & \\
\hline \multicolumn{11}{|l|}{ species composition } \\
\hline fish only & 0.09 & \pm & 0.11 & 2 & & 0.20 & \pm & 0.07 & 3 & \\
\hline fish and other species ${ }^{c}$ & 0.21 & \pm & 0.09 & 23 & & 0.24 & \pm & 0.09 & 10 & \\
\hline other species, no fish ${ }^{c}$ & 0.21 & & & 1 & & 0.14 & & & 1 & \\
\hline \multicolumn{11}{|l|}{ type of ecosystem ${ }^{d}$} \\
\hline coastal & 0.19 & \pm & 0.08 & 14 & & 0.20 & & 0.09 & 7 & \\
\hline oceanic & 0.21 & \pm & 0.11 & 12 & & 0.25 & & 0.08 & 7 & \\
\hline total for marine sites & 0.20 & \pm & 0.10 & 26 & $\mathbf{A} / \mathbf{a}$ & 0.22 & \pm & 0.09 & 14 & $\mathrm{~A} / \mathbf{a}$ \\
\hline \multicolumn{11}{|l|}{ all sites } \\
\hline \multicolumn{11}{|l|}{ latitudinal classes } \\
\hline polar & 0.21 & \pm & 0.07 & 9 & $a$ & 0.26 & \pm & 0.10 & 31 & $a$ \\
\hline temperate & 0.17 & \pm & 0.10 & 78 & $a$ & 0.24 & \pm & 0.07 & 84 & $a$ \\
\hline tropical & 0.13 & \pm & 0.12 & 40 & $b$ & 0.15 & \pm & 0.07 & 9 & $b$ \\
\hline \multicolumn{11}{|l|}{ species composition } \\
\hline fish only & 0.15 & \pm & 0.13 & 32 & & 0.22 & \pm & 0.07 & 4 & \\
\hline fish and other species ${ }^{c}$ & 0.16 & \pm & 0.10 & 91 & & 0.24 & \pm & 0.08 & 116 & \\
\hline other species, no fish ${ }^{c}$ & 0.20 & \pm & 0.09 & 4 & & 0.26 & \pm & 0.12 & 4 & \\
\hline total for all sites & 0.16 & \pm & 0.11 & 127 & B & 0.24 & \pm & 0.08 & 124 & $\mathbf{A}$ \\
\hline
\end{tabular}

${ }^{a}$ TMS values represent individual slopes $(b)$ of simple linear regressions between $\log _{10}[\mathrm{Hg}]$ and $\delta^{15} \mathrm{~N}$ for several sites worldwide. ${ }^{b}$ Categories that share common letters do not differ significantly: BOLD CAPITAL is for comparisons between $\mathrm{Hg}$ species ( $\mathrm{THg}$ vs $\mathrm{MeHg}$ ), lower case bold is for comparison between freshwater and marine sites and lower case italics is for comparisons within levels of a factor for a given $\mathrm{Hg}$ species. ${ }^{c} \mathrm{Other}$ species correspond to phytoplankton, invertebrates, reptiles, birds or mammals. ${ }^{d}$ Coastal food webs were within $20 \mathrm{~km}$ from the coast and depths less than $50 \mathrm{~m}$.

within a food web (eq 1, SI Figure S1). Higher TMS values indicate greater biomagnification potential within a food web.

Biomagnification can also be quantified using trophic level (TL) in place of $\delta^{15} \mathrm{~N}$ values in eq 1 . In this approach, an organism's raw $\delta^{15} \mathrm{~N}$ value is converted into TL using the following equation:

$$
\mathrm{TL}_{\text {consumer }}=\left(\delta^{15} \mathrm{~N}_{\text {consumer }}-\delta^{15} \mathrm{~N}_{\text {baseline }}\right) / \Delta^{15} \mathrm{~N}+\lambda
$$

where $\lambda$ is the trophic level of the baseline organism $(\mathrm{TL}=1$ for primary producers and $\mathrm{TL}=2$ for primary consumers), $\mathrm{TL}_{\text {consumer }}$ is the trophic level of a given consumer, and $\delta^{15} \mathrm{~N}_{\text {consumer }}$ and $\delta^{15} \mathrm{~N}_{\text {baseline }}$ are $\delta^{15} \mathrm{~N}$ values of a given consumer and the baseline organism, respectively. A trophic discrimination factor for $\delta^{15} \mathrm{~N}\left(\Delta^{15} \mathrm{~N}\right)$ of $3.4 \%$ was the most frequently used for aquatic organisms in the reviewed studies (see also refs 33,34) and was therefore chosen for TL calculation.

The trophic magnification factor (TMF), calculated as the antilog of the slope of the relationship between logarithm transformed (to the base 10) $\mathrm{Hg}$ concentration and $\mathrm{TL}$, represents the average biomagnification per TL through the entire food web and can be calculated from the slope $(b)$ of eq 1 by the following:

$$
\mathrm{TMF}=10^{\left(b^{*} 3.4 \%\right)}
$$


where $3.4 \% 0$ is the trophic discrimination factor for $\delta^{15} \mathrm{~N}$ $\left(\Delta^{15} \mathrm{~N}\right)$. TMF represents the increase of $\mathrm{Hg}$ concentration per trophic level (reported in Table S2).

Mercury at the Base of the Food Web. From eq 1, the intercept $(a)$ has been previously considered as an estimate of the concentration of $\mathrm{Hg}$ that is incorporated at the base of the food web. However, the intercept value is intrinsically linked to the slope $^{33}$ (see SI 1 and Table S3 for the complete procedure to test the validity of using the intercept for this purpose). Instead of the intercept to estimate $\mathrm{Hg}$ concentrations at the base of the food chain, we developed three approaches. First, we examined average $\mathrm{Hg}$ concentrations of baseline species ( $\left.\mathrm{Hg}_{\text {baseline }}\right)$ designated as primary consumers (e.g., mussels or snails) that are longer-lived and integrate temporal $\delta^{15} \mathrm{~N}$ variations in the environment ${ }^{12,35}$ although other primary consumer taxa such as zooplankton ${ }^{6}$ have been used. Baseline organisms were usually specifically characterized in studies and their average $\mathrm{Hg}$ and $\delta^{15} \mathrm{~N}$ values were incorporated in the database. In cases where baseline organisms were not specified, values from a primary consumer in the food web from the observations in the individual study were selected and included in the database. When more than one food web was identified at a given site (e.g., pelagic and benthic), corresponding baselines of analogous taxa were used. Second, we estimated $\mathrm{Hg}$ concentration of the baseline organism using the $\delta^{15} \mathrm{~N}$ value of the baseline organism $\left(\mathrm{Hg}_{\delta}{ }^{15}{ }_{\mathrm{N} \text {-baseline }}\right)$ using eq 1 (see SI 1 and Table S3). Third, we estimated $\mathrm{Hg}$ at trophic level $2\left(\mathrm{Hg}_{\mathrm{TL} 2}\right)$ using the slope of the relationship between $\mathrm{Hg}$ and $\mathrm{TL}$ (when available in studies).

Data Acquisition and Database Preparation. We identified published freshwater and marine studies for this meta-analysis using a Web of Knowledge (Thompson Reuters) search for the following keywords: "mercury", "biomagnification", and "nitrogen isotope" as well as a review of references therein. Biomagnification regression equation parameters as well as average $\mathrm{Hg}$ concentrations and $\delta^{15} \mathrm{~N}$ values for identified baseline organisms were extracted. Authors were contacted to obtain information that was unavailable in the publications and these unpublished data were also incorporated in the global database. In cases where we could not obtain raw data directly from the authors, data were extracted from published figures ${ }^{36-39}$ using the program Datagrabber ${ }^{40}$ to generate eq 1. For studies that reported equations in another format (e.g., reduced major axis ${ }^{36}$ ), data were extracted using Datagrabber and were transformed into a consistent format (i.e., simple linear regression). Datagrabber was also used to estimate average $\delta^{15} \mathrm{~N}$ and $\mathrm{Hg}$ values of baseline organisms. ${ }^{41-43}$ Data accuracy and precision for the Datagrabber software are presented in SI 2. When no other option was available, regression equations based on average data were included in the meta-analysis. ${ }^{38,44}$ Many of the authors of this meta-analysis, as well as colleagues, contributed unpublished data sets (see acknowledgments, SI Table S1 and Figure S2). Results of graduate theses were also included. ${ }^{45-50}$ Studies were incorporated in the database, regardless of the significance of the biomagnification regression. Methods for unpublished studies are presented in SI 3.

$\mathrm{Hg}$ concentrations were standardized for moisture content (into wet weight) and data transformation ( $\mathrm{Hg}$ transformed into $\left.\log _{10}\right)$. If $\mathrm{Hg}$ concentrations were reported as dry weight, without specific moisture content, then we assumed a value of $75 \pm 8 \%(n$ $=272),{ }^{51}$ as this was the most frequently reported value in the reviewed studies. Several studies estimated $\mathrm{MeHg}$ (rather than measuring it) in specific taxa such as higher-trophic-level fish species by measuring $\mathrm{THg}$ and assuming 95 or $100 \%$ as $\mathrm{MeHg}$, and then measuring $\mathrm{MeHg}$ in lower-trophic-level species (SI Table S1). In such cases, TMS values were considered to be representative of $\mathrm{MeHg}$ TMS values.

The 69 studies in the database yielded 205 independent sites with 127 and 124 TMS values and over 7200 and 5400 tissue samples for $\mathrm{THg}$ and $\mathrm{MeHg}$, respectively (Table 2). Study sites were distributed worldwide in several types of ecosystems: streams, rivers, wetlands, lakes, estuaries, and oceans (see Table 2 and Table SI for more details on site types and sample sizes), and ranged from low to high input of natural or anthropogenic $\mathrm{Hg}$ (SI Figure S3). Site was the unit of replication of TMS values derived from the data sets.

For freshwater sites, TMS values were paired with in situ physicochemical variables (when available) known to influence mercury trophodynamics. Variables of interest were $\mathrm{pH}$, dissolved organic carbon (DOC), $\mathrm{Hg}$ in water and $\mathrm{Hg}$ in sediments, productivity (chlorophyll- $a[\mathrm{Chl}-a]$, total nitrogen and total phosphorus concentrations), lake surface area, watershed area, and percentage of wetland (Table 1). If physicochemical data were not directly available in the food web study, then values from parallel studies and government databases from the same site were used when available. In addition to measured in situ physico-chemistry variables mentioned immediately above, a complementary approach using GIS (ArcGIS Desktop 9.3.1) was applied to obtain data such as $\mathrm{Hg}$ deposition as a measure of input of $\mathrm{Hg}$ in the system and phosphorus loading as a measure of productivity, as described in SI 4. Atmospheric $\mathrm{Hg}$ deposition data were obtained from Environment Canada (A. Dastoor, unpubl. data; SI Figure S3). Phosphorus loading data were obtained from Vörösmarty et al. ${ }^{52}$ In this present study, physico-chemistry variables will be referred to as "in situ physico-chemistry variables" when they were measured in the field directly and "in silico physicochemistry variables" when they were estimated at each site using GIS. A comparison between in situ and in silico physicochemistry data was done to ensure the validity of the latter for freshwater sites (SI Table S4). Unfortunately, in situ physicochemistry data were generally not reported for marine sites or could not be obtained through other sources and consequently relationships related to physico-chemistry in marine sites could not be tested.

Data Analyses. Both discrete and continuous statistical tests were used to examine effects and trends in biomagnification for the entire data set and for freshwater sites. Discrete tests included t-tests of differences in $\mathrm{THg}$ and $\mathrm{MeHg}$ TMS values. Sites were grouped based on latitudinal classes (polar $\left(66.6^{\circ}\right.$ to $90^{\circ} \mathrm{N}$ or $\left.S\right)$, temperate $\left(23^{\circ}\right.$ to $66.6^{\circ} \mathrm{N}$ or $\left.\mathrm{S}\right)$, tropical $\left(0^{\circ}\right.$ to $23^{\circ} \mathrm{N}$ or $\left.\mathrm{S}\right)$ ), type of ecosystem (streams and rivers, lakes, and marine (coastal and open ocean)), species composition ( $i$, fish only; $i$, fish and other taxa; and iii, no fish) and productivity status (oligotrophic, mesotrophic, eutrophic, and hypereutrophic, based on total phosphorus values ${ }^{53}$ ). Those factors were tested using analysis of variances (ANOVA) with TMS values as the dependent variable, followed by a Tukey's test for differences among levels of factors.

For the continuous tests, simple linear regressions and correlations were used to test the relationships between TMS values and physicochemical variables (in situ and in silico). Multiple linear regressions examining the combined influence of different physicochemical variables on TMS were done with model selection by Akaike information criterion (AIC) to determine the best and most parsimonious model. ${ }^{54}$ The model with the lowest AIC was selected. Multiple linear regressions were done on groups of variables with standardized (mean $=0$, 
$\mathrm{SD}=1$, to remove the effect of scale differences between variables ${ }^{54}$ ) TMS values as dependent variables and standardized physico-chemistry variables as independent variables. Multicollinearity was tested by variance inflation factor with values below 5 being considered acceptable. ${ }^{54}$

Statistical analyses were performed using version 2.13 .2 of the $\mathrm{R}$ statistical program. ${ }^{55}$ Lilliefors tests were done on residuals after each statistical test to ensure normality of variables. Nonparametric tests were used when assumptions were not met. When possible, statistical analyses were done separately on freshwater sites, marine sites, and all sites combined. However, emphasis was put on freshwater sites in this study because more sites and more physico-chemistry data were available for this type of ecosystem.

\section{RESULTS}

Food Web Characteristics. The average $( \pm S D)$ range of trophic levels included in food webs (trophic level of top predator - trophic level of baseline) based on $\delta^{15} \mathrm{~N}$ (eq 2) was $1.7 \pm 0.7$ for $\mathrm{THg}$ and $1.8 \pm 0.8$ for $\mathrm{MeHg}$. Trophic level of the upper consumer organism in the food web (eq 2) averaged $3.7 \pm$ 0.8 for $\mathrm{THg}$ and $3.8 \pm 0.8$ for $\mathrm{MeHg}$.

Average Biomagnification of $\mathrm{THg}$ and $\mathrm{MeHg}$. Globally, THg TMS values $(0.16 \pm 0.11)$ were significantly lower than those based on $\mathrm{MeHg}(0.24 \pm 0.08$, Student's $t$-test: $t=6.9, p<$ 0.001; Table 2, Figure 1). When freshwater and marine sites were

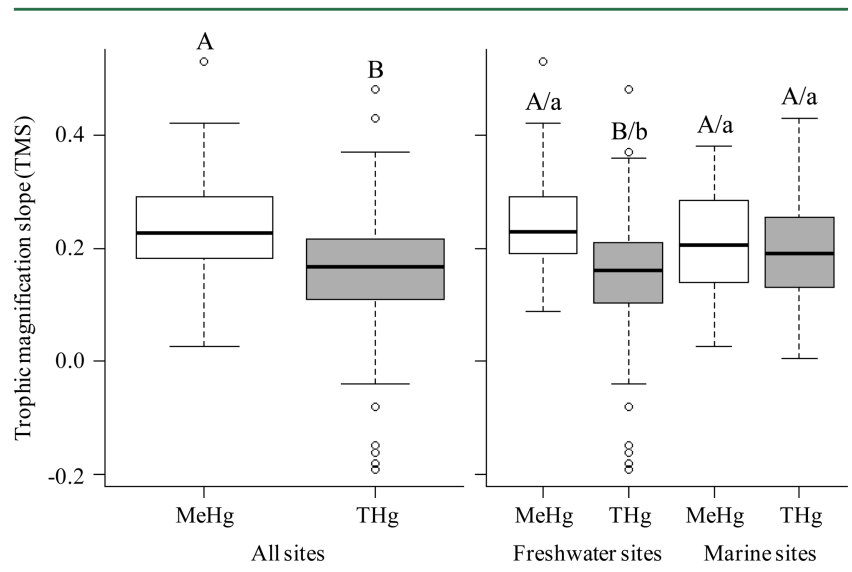

Figure 1. Boxplot of $\mathrm{MeHg}$ (white) and $\mathrm{THg}$ (gray) trophic magnification slopes (TMS values) based on wet weight for all sites (left panel) and freshwater sites and marine sites (right panel) reviewed in this study. Categories that share common letters do not differ significantly: capital letters are for comparisons between $\mathrm{Hg}$ species ( $\mathrm{THg}$ vs $\mathrm{MeHg}$ ) and lower case letters are for comparison between freshwater and marine site.

considered separately, freshwater food web THg slopes were still significantly lower than $\mathrm{MeHg}$ slopes $(t=7.3, p<0.001)$, but marine sites did not have any significant differences between $\mathrm{MeHg}$ and THg TMS values $(t=0.7, p=0.50$, Figure 1$)$.

TMS values from marine sites were higher than those from freshwater sites for $\mathrm{THg}$, but not for $\mathrm{MeHg}$ (Mann-WhitneyWilcoxon, THg: $W=881, p=0.01$, MeHg: $W=853, p=0.06$, Figure 1). Within freshwater systems, TMS values for lentic ecosystems were higher than those of lotic ecosystems for $\mathrm{THg}$ $(W=1552, p=0.026)$, but lower for $\mathrm{MeHg}(W=807, p=0.003)$. Within marine systems, there was no difference between coastal and open water sites (THg: $t=-0.5, p=0.618$, MeHg: $t=-1.1$, $p=0.291$; Table 2).
Effect of Latitude on $\mathrm{Hg}$ Biomagnification. $\mathrm{THg}$ and $\mathrm{MeHg}$ TMS values were both significantly higher in polar and temperate sites when compared to tropical sites (KruskalWallis, THg: $\chi^{2}=7.0, p=0.03$, MeHg: $\chi^{2}=12.1, p=0.002$ ). Within freshwater sites, higher MeHg TMS values were also found in polar and temperate sites than in tropical sites $\left(\chi^{2}=\right.$ 12.4, $p=0.002$ ). Regression analyses also found a positive relationship between TMS values and latitude for all sites combined and for freshwater food webs only (Figure 2). In summary, both discrete statistics using latitudinal classes and continuous statistics demonstrate that polar and temperate sites consistently have higher $\mathrm{Hg}$ TMS values while tropical sites have among the lowest TMS values.

Effect of Food Web Composition on Hg Biomagnification. $\mathrm{THg}$ or $\mathrm{MeHg}$ biomagnification was not different for studies that examined food webs composed of fish only, fish and other taxa (phytoplankton, invertebrates, reptiles, birds, or mammals), or nonfish taxa in freshwater sites (ANOVA, THg: $F$ $=0.5, p=0.59$, MeHg: $F=1.2, p=0.31)$, marine sites $(\mathrm{THg}: F=$ 1.7, $p=0.20$, MeHg: $F=0.7, p=0.52$ ) or all sites combined (THg: $F=0.3, p=0.73$, MeHg: $F=0.3, p=0.75$; Table 2). There was also no relationship between percentage of endotherms in a food web and TMS for freshwater sites (linear regression, THg: $F$ $=1.5, p=0.22, \mathrm{MeHg}, F=1.0, p=0.31)$ or marine sites (THg: $F$ $=0.6, p=0.46, \mathrm{MeHg}, \mathrm{F}=1.0, p=0.34)$.

Effect of in Situ Physico-chemistry on Hg Biomagnification-Freshwater Sites. Using in situ water chemistry data (measured directly in the field at the reviewed study sites), $\mathrm{THg}$ and $\mathrm{MeHg}$ TMS values in freshwater sites were not affected by productivity status (from oligotrophic to hypereutrophic), categorized using total phosphorus (ANOVA, THg: $F=1.7, p$ $=0.18$, MeHg: $F=1.7, p=0.17$, Table 2). When examined as continuous variables, there was a moderate positive correlation between Chl- $a$ and THg TMS $\left(r^{2}=0.18, p=0.010\right)$, but a moderate negative correlation for MeHg TMS $\left(r^{2}=-0.22, p=\right.$ 0.003; Table 1). In addition, a moderate positive relationship between DOC and slopes was found for THg $\left(r^{2}=0.14, p=\right.$ $0.014)$, but not for $\mathrm{MeHg}\left(r^{2}=0.04, p=0.087\right)$. However, there were no significant relationships between total phosphorus and TMS values (THg: $r^{2}=0.01, p=0.38$, MeHg: $r^{2}=-0.02, p=$ 0.26 ) or between total nitrogen and TMS values (THg: $r^{2}<0.01$, $p=0.80$, MeHg: $r^{2}<0.01, p=0.90$, Table 1$)$.

There was a negative relationship between aqueous $\mathrm{Hg}$ concentration and MeHg TMS $\left(r^{2}=0.16, p=0.006\right)$, but not for THg TMS $\left(r^{2}=-0.01, p=0.58\right)$. No other in situ water physicochemistry variables ( $\mathrm{Hg}$ in sediments, $\mathrm{pH}$, percentage of wetland, lake area and watershed area) showed any relationship with TMS values (Table 1).

The multiple linear regression model for THg TMS values including $\mathrm{pH}$, total phosphorus and DOC was not significant for the overall model $\left(F=3.1, R^{2}=0.20, p=0.06\right)$, but total phosphorus showed a negative partial standardized regression coefficient in the model $\left(b^{\prime}=-0.24, p=0.035\right.$, SI Table S5). However, $25 \%$ of the variation in $\mathrm{MeHg}$ slopes was accounted for (in decreasing order of hierarchical partitioning) by $\mathrm{pH}\left(b^{\prime}=\right.$ $0.35)$, total phosphorus $\left(b^{\prime}=-0.32\right)$ and DOC $\left(b^{\prime}=0.27\right.$; overall model: $F=4.4, R^{2}=0.25, p<0.001$, SI Table S5). A multiple linear regression model including $\mathrm{Hg}_{\text {baseline }}$ and aqueous $\mathrm{Hg}$ showed that $\mathrm{Hg}_{\text {baseline }}\left(b^{\prime}=-0.52\right)$ accounted for $21 \%$ of the variation of $\mathrm{MeHg}$ slopes $(F=5.6, p=0.007)$, whereas aqueous $\mathrm{Hg}$ concentration was not significant $\left(b^{\prime}=-0.27, p=0.18\right)$. $\mathrm{Hg}_{\text {baseline }}$ and aqueous $\mathrm{Hg}$ concentration had no effect on $\mathrm{THg}$ slopes $\left(F=0.3, R^{2}=0.04, p=0.76\right)$. 


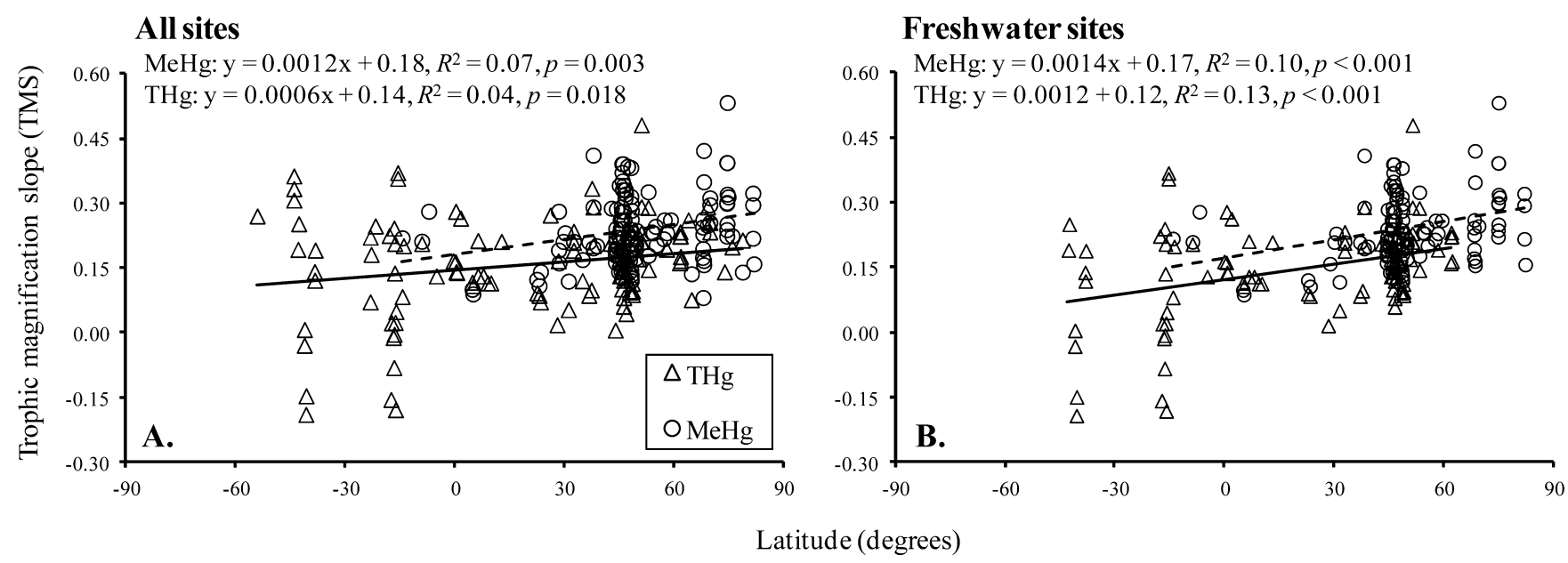

Figure 2. Relationships between $\mathrm{THg}$ (triangles) and $\mathrm{MeHg}$ (circles) trophic magnification slopes (TMS) against latitude for all sites (A) and freshwater sites (B). TMS values represent individual slopes $(b)$ of simple linear regressions between $\log _{10}[\mathrm{Hg}]$ and $\delta^{15} \mathrm{~N}$ for several sites worldwide.

Effect of in Silico Physico-chemistry on Hg Biomagnification-Freshwater Sites. MeHg TMS values in freshwater sites showed a significant negative relationship with GIS-derived (in silico) atmospheric $\mathrm{Hg}$ deposition (A. Dastoor, Environment Canada, unpubl. data, linear regression, $F=12.9, R^{2}=0.11, p<$ $0.001)$, but it was not the case for THg TMS values $\left(F=2.4, R^{2}=\right.$ $0.01, p=0.12$, Table 1 ).

Freshwater THg TMS values demonstrated a positive significant relationship with in silico (GIS-derived) phosphorus loading $\left(F=6.9, R^{2}=0.07, p=0.01\right)$, whereas $\mathrm{MeHg}$ TMS values were negatively related to phosphorus loading $\left(F=11.7, R^{2}=\right.$ $0.10, p<0.001$, Table 1 ).

In a multiple linear regression model, $\mathrm{THg}$ TMS values were explained by $\mathrm{Hg}$ deposition $\left(b^{\prime}=-0.26\right)$ and phosphorus loading $\left(b^{\prime}=0.33\right)$ with an overall model accounting for $13 \%$ of the variation $(F=7.4, p=0.001$; SI Table S5). MeHg slopes were also explained by $\mathrm{Hg}$ deposition $\left(b^{\prime}=-0.19\right)$ and phosphorus loading $\left(b^{\prime}=-0.20\right)$ with an overall model accounting for $12 \%$ of the variation $(F=7.5, p<0.001)$.

\section{DISCUSSION}

Biomagnification of $\mathrm{THg}$ and $\mathrm{MeHg}$. Over the past three decades, many studies have used $\delta^{15} \mathrm{~N}$ to estimate $\mathrm{Hg}$ biomagnification, providing the opportunity for a comprehensive literature review of factors affecting $\mathrm{Hg}$ biomagnification in aquatic systems. We found that biomagnification was highly variable among all reviewed sites. When all sites were combined, the average $( \pm S D)$ TMS for $\mathrm{THg}$ and $\mathrm{MeHg}$ were $0.16 \pm 0.11$ and $0.24 \pm 0.08$, respectively. These TMS values can be converted to TMF values using eq 3 (see SI Table S2 for a complete list of TMF values) and indicate that $\mathrm{THg}$ and $\mathrm{MeHg}$ increase by a factor of $4.7 \pm 4.7$ and $8.1 \pm 7.2$ per trophic level, respectively. The average TMS value for freshwater sites was 0.15 $\pm 0.11(\mathrm{TMF}=4.3 \pm 4.8)$ and $0.24 \pm 0.08(\mathrm{TMF}=8.3 \pm 7.5)$ for $\mathrm{THg}$ and $\mathrm{MeHg}$, respectively. For marine sites, the average TMS was $0.20 \pm 0.10(\mathrm{TMF}=6.2 \pm 4.1)$ and $0.22 \pm 0.09(\mathrm{TMF}=7.0$ \pm 4.9) for $\mathrm{THg}$ and $\mathrm{MeHg}$, respectively.

Despite intensive comparative studies on $\mathrm{Hg}$ biomagnification conducted at a regional scale, ${ }^{7,18,49,56-63}$ no general consensus has emerged regarding the main variables affecting $\mathrm{Hg}$ biomagnification in aquatic ecosystems. Here, we present a synthesis of $\mathrm{Hg}$ biomagnification in aquatic food webs on a global scale and explore physical, chemical and biological factors that could explain the observed variability in TMS values.

Latitude and $\mathrm{Hg}$ Biomagnification. To the best of our knowledge, this is the first study to test and show that global biomagnification of $\mathrm{THg}$ or $\mathrm{MeHg}$ was positively related to latitude. Several mechanisms related to temperature may explain these latitudinal trends. First, warmer temperatures stimulate growth rates in aquatic organisms which in turn decreases the amount of $\mathrm{Hg}$ per unit of body mass (growth biodilution) as opposed to colder temperatures where growth rate is suppressed. $^{26}$ In warmer regions, trophic transfer efficiency of $\mathrm{Hg}$ would be reduced at every trophic step therefore reducing biomagnification (TMS). Second, colder temperatures lead to slower excretion rates of $\mathrm{MeHg}$ resulting in a higher accumulation in organisms. ${ }^{24}$ It is expected that higher accumulation would affect all organisms along the food web, albeit not equally, and would have repercussions on the overall TMS value. Third, we hypothesize that simpler food webs at higher latitudes, ${ }^{64}$ as characterized by a low species diversity, ${ }^{65}$ could lead to higher $\mathrm{Hg}$ biomagnification than in more complex and more diverse food webs at lower latitudes. With $\mathrm{Hg}$ increasing exponentially with trophic levels, a slight change in dietary trophic level along the food chain would have implications for $\mathrm{Hg}$ concentrations and therefore on the overall TMS. Hence, high diversity (large choice of prey for a given consumer) could potentially reduce efficiency of $\mathrm{Hg}$ trophic transfer.

The latitudinal relationship with $\mathrm{Hg}$ biomagnification found in our review is likely conservative because lower $\delta^{15} \mathrm{~N}$ trophic discrimination factors $\left(\Delta^{15} \mathrm{~N}\right)$ may occur in the tropics ${ }^{66}$ and should, in principle, lead to higher TMS values in that region compared to temperate or polar latitudes (see SI 5, Table S6 and Figure S4). On the contrary, our results show lower TMS in the tropics despite lower $\Delta^{15} \mathrm{~N}$. These data therefore indicate that latitude plays a role in $\mathrm{Hg}$ biomagnification, although the mechanism remains unclear. Additional studies specifically testing the effect of food web composition or structure and temperature on $\mathrm{Hg}$ biomagnification are needed to address the mechanism responsible for the observed latitudinal effect.

Although latitude was linked to TMS in our study, there are likely other drivers than only temperature. Indeed, latitude was correlated with several physico-chemistry variables among $\mathrm{THg}$ sites (such as DOC, Chl- $a$, and total phosphorus) and among 
MeHg sites ( $\mathrm{pH}, \mathrm{DOC}$, Chl- $a$, total phosphorus, phosphorus loading, aqueous $\mathrm{Hg}$, sediment $\mathrm{Hg}$ and $\mathrm{Hg}$ deposition, SI Table S4). It is therefore likely that several variables are acting in synergy to cause the observed latitudinal trends. It is especially hard to dissociate ecosystem productivity variables (e.g., total phosphorus and Chl-a) from each other and from latitude as they are not independent and are driven by temperature. Variables related to ecosystem productivity following a latitudinal gradient could also explain the observed trend in TMS values and are discussed below.

Physiology and $\mathrm{Hg}$ Biomagnification. $\mathrm{Hg}$ biomagnification was expected to be influenced by the energy requirement of organisms included in a given food web. Endotherms have higher energy requirements and lower food conversion efficiencies than ectotherms; thus, they have a higher potential intake of $\mathrm{Hg}$ (higher weight-specific metabolic rate) compared to ectotherms. Inclusion of endotherms in food webs was hypothesized to increase $\mathrm{Hg}$ biomagnification slopes. However, neither the species composition nor the percentage of endotherms in food webs affected TMS values. This is in contrast to a study by Hallanger et al. ${ }^{67}$ who showed that marine food webs including endotherms have higher biomagnification of persistent organic pollutants than those excluding endotherms.

Physico-chemistry and Hg Biomagnification. It is well established that $\mathrm{Hg}$ concentrations in aquatic organisms are affected by the physicochemical characteristics of the systems they inhabit. ${ }^{10,14,16,58}$ The focus of our study, however, was on determining if $\mathrm{Hg}$ biomagnification (rather than $\mathrm{Hg}$ concentrations) was affected by those variables. Herein several physicochemistry variables were related to TMS values and relationships were most consistent (same direction of outcome for both $\mathrm{THg}$ and $\mathrm{MeHg}$ TMS in Table 1) for DOC (+), $\mathrm{Hg}$ deposition (-) and total phosphorus (-). Most of these trends agree with known relationships of these variables with $\mathrm{Hg}$ bioaccumulation in biota, ${ }^{10,17,25}$ whereas contradictory results were found for DOC.

While DOC binds $\mathrm{MeHg}$ and thereby increases the transport of $\mathrm{MeHg}$ from wetlands to lakes, ${ }^{68} \mathrm{DOC}$ can also reduce trophic transfer of $\mathrm{Hg}$ from one organism to another, ${ }^{10,69,70}$ with lower bioaccumulation in lakes with high DOC. ${ }^{58,71}$ Although Rolfhus et al. ${ }^{58}$ found that water $\mathrm{MeHg}$ concentrations increased with aqueous DOC concentrations across multiple lakes, bioaccumulation factors ( $\mathrm{BAF}=\mathrm{Hg}$ in biota/ $\mathrm{Hg}$ in water) decreased while TMS values remained constant, suggesting that $\mathrm{Hg}$ in upper trophic levels was primarily defined at the base of the food web in those lakes. ${ }^{58}$ Dittman and Driscoll ${ }^{71}$ also found a negative correlation between DOC and BAF suggesting that DOC could limit uptake of $\mathrm{Hg}$ by organisms. Our study showed positive relationships between TMS values and DOC. Contradictory relationships between previous studies and our current metaanalysis reflect the complexity of DOC as a predictor of $\mathrm{Hg}$ in aquatic organisms and could suggest a role for DOC effects on higher-trophic-level organisms.

Although higher $\mathrm{Hg}$ concentrations at the base of a given system ( $\mathrm{Hg}$ deposition, aqueous $\mathrm{Hg}, \mathrm{Hg}_{\text {baseline }}$ ) cause higher concentrations in aquatic organisms, ${ }^{14,72-74}$ TMS values were expected to decrease when basal inputs increase. ${ }^{17-19}$ This $\mathrm{Hg}$ accumulation paradox may be due to competitive uptake kinetics (with other elements) and regulation mechanisms at the cellular level of organisms. ${ }^{20-22}$ Our study showed that $\mathrm{Hg}$ biomagnification was indeed higher in systems with lower $\mathrm{Hg}$ deposition (as modeled by GRAHM, A. Dastoor, Environment Canada, unpubl. data) and therefore with less $\mathrm{Hg}$ available in the system.
Moreover, because $\mathrm{Hg}$ deposition was positively correlated to $\mathrm{MeHg}_{\text {baseline }}\left(r^{2}=0.05, p=0.025\right)$, this suggests that prey concentrations control $\mathrm{Hg}$ biomagnification as has been demonstrated in laboratory studies ${ }^{19}$ and for predator-prey relationships in rivers. ${ }^{18}$ Consequently, systems with increased $\mathrm{Hg}$ loading may not exhibit a proportional response in concentrations in top predators because of lower TMS values in systems with higher $\mathrm{Hg}_{\text {baseline. }}$. An alternative explanation for $\mathrm{MeHg}$ is that latitude (being negatively correlated with $\mathrm{Hg}$ deposition at $\mathrm{MeHg}$ sites, SI Table S4) has the highest impact on TMS and that low $\mathrm{Hg}$ deposition coincides with high latitudes where high MeHg TMS are found. That explanation would not be valid for $\mathrm{THg}$ sites however since there was no correlation between latitude and $\mathrm{Hg}$ deposition.

Increased system productivity, in the form of algal blooms, can reduce the uptake of $\mathrm{MeHg}$ by higher-trophic-level organisms such as zooplankton ${ }^{25}$ because the pool of $\mathrm{Hg}$ is diluted by a larger amount of biomass, therefore reducing concentrations in predators. In our study, we found negative relationships with phosphorus consistent with previous studies. ${ }^{25}$ In contrast, Kidd et al. ${ }^{7}$ found that biomagnification slopes were positively related to total phosphorus in 14 Canadian lakes. With the results of our study, we believe that biomass dilution (i.e., due to high productivity $^{25}$ ) could reduce $\mathrm{Hg}$ uptake in lower trophic levels, but more importantly, high primary productivity could increase growth rate of higher-trophic-level species ${ }^{26,28,75}$ (i.e., due to better food quality ${ }^{27}$ ) therefore reducing the overall TMS.

There were contradictory relationships between $\mathrm{THg}$ and MeHg TMS with other physicochemical variables such as Chl-a, $\mathrm{pH}$, phosphorus loading, and $\mathrm{Hg}$ concentration in water. Unfortunately, since studies did not systematically report all in situ physico-chemistry variables, we could only examine pairwise relationships or a limited number of combined variables (i.e., multiple linear regressions, SI Table S5). Other considerations of the studies in our review are the different methods used to measure a specific in situ physicochemical variable, and that most existing data were from single measurements that may not be representative of a given system. It is therefore possible that some of those variables have an impact on $\mathrm{Hg}$ biomagnification, but our incomplete data set could not detect it.

Although studies that tested the effect of specific physicochemistry variables on $\mathrm{Hg}$ concentrations in biota across multiple sites have found significant relationships, ${ }^{10,14,16,58}$ those linking physico-chemistry to $\mathrm{Hg}$ biomagnification across multiple sites have not been as conclusive. ${ }^{18,59,61,63}$ This may stem from insufficient statistical power in those studies to detect differences in biomagnification slopes. For example, a power analysis for $\mathrm{THg}$ TMS in freshwater sites vs latitude (Figure $2 \mathrm{~b}$ ) showed that 46 sites would be required to detect a significant effect (power $=$ 0.8 , effect size $\left(R^{2}\right)=0.13$, well above the typical number of sites examined in a given study. This further highlights the important role of meta-analyses in evaluating $\mathrm{Hg}$ biomagnification trends and in generating new testable hypotheses.

In this present study, we found that $\mathrm{MeHg}$ biomagnified more efficiently than $\mathrm{THg}$, and this was expected since $\mathrm{MeHg}$ is the $\mathrm{Hg}$ species known to bioaccumulate and biomagnify. ${ }^{10} \mathrm{We}$ also found that biomagnification increased with latitude and this phenomenon was likely due to a combination of interdependent variables related to temperature. The most plausible explanation is the combined effect of dilution due to growth rate and biomass dilution in highly productive, warm systems that could decrease the trophic transfer of $\mathrm{Hg}$ in aquatic food webs. In addition, concentrations of $\mathrm{Hg}$ in a system (as measured by $\mathrm{Hg}$ 
deposition) could either act as a suppressor to biomagnification ( $\mathrm{Hg}$ accumulation paradox ${ }^{20-22}$ ) or is simply the result of latitudinal trends with TMS being stronger than $\mathrm{Hg}$ deposition. Since physico-chemistry data were not systematically reported among the reviewed studies, we were unable to reach strong conclusions regarding specific processes and mechanisms regarding some of those variables on $\mathrm{Hg}$ biomagnification. We therefore urge for more studies that test specific sets of hypotheses on a large number of sites.

Recommendations for Future Studies. On the basis of our observations during this meta-analysis, we recommend following the guidelines for measuring biomagnification of contaminants in food webs provided by Borgå et al. ${ }^{33}$ (see also SI 6) plus these additional recommendations for future studies of $\mathrm{Hg}$ biomagnification (see also SI 7):

- Examine a large number of sites that vary in specific physical and chemical characteristics (e.g., pH, DOC, $\mathrm{Hg}$ in water and productivity) to better understand the effects of ecosystem context on $\mathrm{Hg}$ biomagnification and to determine factors affecting TMS. As stated above, a power analysis should be done to determine the appropriate number of sites.

- Adequately characterize baselines of food webs using a representative primary consumer (trophic level $=2$ ) species. We suggest using this baseline to interpret $\mathrm{Hg}$ at the base of the food web $\left(\mathrm{Hg}_{\text {baseline }}\right)$ and avoid erroneous interpretation of the $\mathrm{Hg}$ vs $\delta^{15} \mathrm{~N}$ intercept. We also suggest calculating and reporting the metrics described in our study, namely $\mathrm{Hg}_{\delta}{ }^{15}$ N-baseline and $\mathrm{Hg}_{\mathrm{TL} 2}$ (see Materials and Methods and SI 1).

- Report slope and intercept error estimates (e.g., confidence interval) and effect size $\left(R^{2}\right)$ of the $\mathrm{Hg}$ vs $\delta^{15} \mathrm{~N}$ relationship as well as significance levels. In addition, trophic level should be calculated and the $\mathrm{Hg}$ vs $\mathrm{TL}$ relationship should be reported.

- Calculate regression models for each independent food web after confirming that species are operationally defined by dietary dependence among trophic levels ${ }^{63}$ (e.g., pelagic food web vs benthic food web). Organisms from disconnected systems (e.g., different lakes) or those that are migratory or not linked to similar carbon sources should not be pooled together.

- Measure the entry of both $\mathrm{THg}$ and $\mathrm{MeHg}$ into the food chain at the water/primary production interface (e.g., bioaccumulation factor: $\mathrm{BAF}=\mathrm{Hg}$ in biota $/ \mathrm{Hg}$ in water ${ }^{10}$ and biota-sediment accumulation factor: $\mathrm{BSAF}=\mathrm{Hg}$ in biota/ $\mathrm{Hg}$ in sediment ${ }^{76}$ ).

By following these recommendations, it should be possible to describe some of the currently unexplained variability in TMS and improve our understanding of the global cycling of $\mathrm{Hg}$ through food webs.

\section{ASSOCIATED CONTENT}

\section{S Supporting Information}

Testing the validity of the equation intercept as an indicator of mercury concentration at the base of the food web (SI 1); quality assurance and quality control on the use of Datagrabber (SI 2); methods for unpublished results (SI 3); physico-chemistry data using GIS (SI 4); effect of $\delta^{15} \mathrm{~N}$ trophic dicrimination factor difference with latitude on TMS (SI 5); summary of guidelines for mercury studies (SI 6); and other recommendations for future studies (SI 7), including additional method descriptions, results, discussions, data tables, and figures. This information is available free of charge via the Internet at http://pubs.acs.org.

\section{AUTHOR INFORMATION}

\section{Corresponding Author}

*E-mail: lavoie.raphael@gmail.com.

\section{Notes}

The authors declare no competing financial interest.

\section{ACKNOWLEDGMENTS}

We thank the following generous authors (alphabetical order) for sharing data: Marina Arcagni, Lisa Atwell and Keith Hobson, John Chételat and Marc Amyot, Meredith Clayden, Baoshan Cui, Lara Dehn, Yannick Dominique, Marlene Evans, Nikolaus Gantner, Patrick Gorski, Eunhee Kim, Sae Yun Kwon, Jenifer McIntyre, Carlos Molina, Michael Newman, Vincent Perrot, Frank Riget, Kristopher Rolfhus, Heidi Swanson, Jennifer Thera, Piet Verburg, and Liang Zhang. A special thank you to Dr. Ashu Dastoor (Environment Canada) for sharing the latest data of the GRAHM Hg deposition model. We thank David Depew for guidance in ArcGIS. We thank Roxanne Razavi for discussions and comments. Finally, we thank all authors and collaborators of the cited studies who made this meta-analysis possible. This study was supported by a Natural Sciences and Engineering Research Council (NSERC) Alexander Graham Bell Canada Graduate Scholarship, a Doctoral research scholarship from the Fonds Québécois de la Recherche sur la Nature et les Technologies (FQRNT) and an Ontario Graduate Scholarship to R.A.L. and by NSERC Canada Research Chair and Discovery funding to K.A.K. and L.M.C.

\section{REFERENCES}

(1) Streets, D. G.; Devane, M. K.; Lu, Z. F.; Bond, T. C.; Sunderland, E. M.; Jacob, D. J. All-time releases of mercury to the atmosphere from human activities. Environ. Sci. Technol. 2011, 45, 10485-10491.

(2) Amos, H. M.; Jacob, D. J.; Streets, D. G.; Sunderland, E. M. Legacy impacts of all-time anthropogenic emissions on the global mercury cycle. Global Biogeochem. Cycles 2013, 27, 410-421.

(3) Selin, N. E. Global biogeochemical cycling of mercury: A review. Annu. Rev. Environ. Resour. 2009, 34, 43-63.

(4) Mergler, D.; Anderson, H. A.; Chan, L. H. M.; Mahaffey, K. R; Murray, M.; Sakamoto, M.; Stern, A. H. Methylmercury exposure and health effects in humans: A worldwide concern. Ambio 2007, 36, 3-11.

(5) Kidd, K. A.; Clayden, M.; Jardine, T. D. Bioaccumulation and Biomagnification of Mercury in Food Webs. In Environmental Chemistry and Toxicology of Mercury; Liu, G., Cai, Y., O'Driscoll, N., Eds.; John Wiley \& Sons, Inc.: Hoboken, NJ, 2012; pp 453-499.

(6) Campbell, L. M.; Norstrom, R. J.; Hobson, K. A.; Muir, D. C. G.; Backus, S.; Fisk, A. T. Mercury and other trace elements in a pelagic Arctic marine food web (Northwater Polynya, Baffin Bay). Sci. Total Environ. 2005, 351, 247-263.

(7) Kidd, K. A.; Muir, D. C. G.; Evans, M. S.; Wang, X.; Whittle, M.; Swanson, H. K.; Johnston, T.; Guilford, S. Biomagnification of mercury through lake trout (Salvelinus namaycush) food webs of lakes with different physical, chemical and biological characteristics. Sci. Total Environ. 2012, 438, 135-143.

(8) Kim, E.; Kim, H.; Shin, K. H.; Kim, M. S.; Kundu, S. R.; Lee, B. G.; Han, S. Biomagnification of mercury through the benthic food webs of a temperate estuary: Masan Bay, Korea. Environ. Toxicol. Chem. 2012, 31, 1254-1263.

(9) Molina, C. I.; Gibon, F. M.; Duprey, J. L.; Dominguez, E.; Guimaraes, J. R. D.; Roulet, M. Transfer of mercury and methylmercury along macroinvertebrate food chains in a floodplain lake of the Beni River, Bolivian Amazonia. Sci. Total Environ. 2010, 408, 3382-3391. 
(10) Watras, C. J.; Back, R. C.; Halvorsen, S.; Hudson, R. J. M.; Morrison, K. A.; Wente, S. P. Bioaccumulation of mercury in pelagic freshwater food webs. Sci. Total Environ. 1998, 219, 183-208.

(11) Cabana, G.; Rasmussen, J. B. Modeling food-chain structure and contaminant bioaccumulation using stable nitrogen isotopes. Nature 1994, 372, 255-257.

(12) Post, D. M. Using stable isotopes to estimate trophic position: Models, methods, and assumptions. Ecology 2002, 83, 703-718.

(13) Yoshinaga, J.; Suzuki, T.; Hongo, T.; Minagawa, M.; Ohtsuka, R.j Kawabe, T.; Inaoka, T.; Akimichi, T. Mercury concentration correlates with the nitrogen stable isotope ratio in the animal food of Papuans. Ecotoxicol. Environ. Saf. 1992, 24, 37-45.

(14) Hammerschmidt, C. R.; Fitzgerald, W. F. Methylmercury in freshwater fish linked to atmospheric mercury deposition. Environ. Sci. Technol. 2006, 40, 7764-7770.

(15) Hammerschmidt, C. R.; Fitzgerald, W. F. Methylmercury in mosquitoes related to atmospheric mercury deposition and contamination. Environ. Sci. Technol. 2005, 39, 3034-3039.

(16) Burgess, N. M.; Meyer, M. W. Methylmercury exposure associated with reduced productivity in common loons. Ecotoxicology 2008, 17, 83-91.

(17) DeForest, D. K.; Brix, K. V.; Adams, W. J. Assessing metal bioaccumulation in aquatic environments: the inverse relationship between bioaccumulation factors, trophic transfer factors and exposure concentration. Aquat. Toxicol. 2007, 84, 236-246.

(18) Jardine, T. D.; Kidd, K. A.; O'Driscoll, N. Food web analysis reveals effects of $\mathrm{pH}$ on mercury bioaccumulation at multiple trophic levels in streams. Aquat. Toxicol. 2013, 132-133, 46-52.

(19) McGeer, J. C.; Brix, K. V.; Skeaff, J. M.; DeForest, D. K.; Brigham, S. I.; Adams, W. J.; Green, A. Inverse relationship between bioconcentration factor and exposure concentration for metals: Implications for hazard assessment of metals in the aquatic environment. Environ. Toxicol. Chem. 2003, 22, 1017-1037.

(20) Phillips, D. J. H.; Rainbow, P. S. Strategies of trace-metal sequestration in aquatic organisms. Mar. Environ. Res. 1989, 28, 207210.

(21) Borgmann, U.; Norwood, W. P. Kinetics of excess (above background) copper and zinc in Hyalella azteca and their relationship to chronic toxicity. Can. J. Fish. Aquat. Sci. 1995, 52, 864-874.

(22) White, S. L.; Rainbow, P. S. Regulation and accumulation of copper, zinc, and cadmium by the shrimp Palaemon elegans. Mar. Ecol.: Prog. Ser. 1982, 8, 95-101.

(23) Greenfield, B. K.; Hrabik, T. R.; Harvey, C. J.; Carpenter, S. R. Predicting mercury levels in yellow perch: use of water chemistry, trophic ecology, and spatial traits. Can. J. Fish. Aquat. Sci. 2001, 58, $1419-1429$.

(24) Trudel, M.; Rasmussen, J. B. Modeling the elimination of mercury by fish. Environ. Sci. Technol. 1997, 31, 1716-1722.

(25) Pickhardt, P. C.; Folt, C. L.; Chen, C. Y.; Klaue, B.; Blum, J. D. Algal blooms reduce the uptake of toxic methylmercury in freshwater food webs. Proc. Natl. Acad. Sci. U.S.A. 2002, 99, 4419-4423.

(26) Simoneau, M.; Lucotte, M.; Garceau, S.; Laliberte, D. Fish growth rates modulate mercury concentrations in walleye (Sander vitreus) from eastern Canadian lakes. Environ. Res. 2005, 98, 73-82.

(27) Karimi, R.; Chen, C. Y.; Pickhardt, P. C.; Fisher, N. S.; Folt, C. L. Stoichiometric controls of mercury dilution by growth. Proc. Natl. Acad. Sci. U.S.A. 2007, 104, 7477-7482.

(28) Ward, D. M.; Nislow, K. H.; Chen, C. Y.; Folt, C. L. Reduced trace element concentrations in fast-growing juvenile Atlantic salmon in natural streams. Environ. Sci. Technol. 2010, 44, 3245-3251.

(29) Pauly, D. Tropical fishes: Patterns and propensities. J. Fish Biol. 1998, 53, 1-17.

(30) Gross, M. R.; Coleman, R. M.; McDowall, R. M. Aquatic productivity and the evolution of diadromous fish migration. Science 1988, 239, 1291-1293.

(31) Layman, C. A.; Winemiller, K. O.; Arrington, D. A.; Jepsen, D. B. Body size and trophic position in a diverse tropical food web. Ecology 2005, 86, 2530-2535.
(32) Kwon, S. Y.; McIntyre, P. B.; Flecker, A. S.; Campbell, L. M. Mercury biomagnification in the food web of a neotropical stream. Sci. Total Environ. 2012, 417, 92-97.

(33) Borgå, K.; Kidd, K. A.; Muir, D. C. G.; Berglund, O.; Conder, J. M.; Gobas, F. A. P. C.; Kucklick, J.; Malm, O.; Powell, D. E. Trophic magnification factors: Considerations of ecology, ecosystems, and study design. Integr. Environ. Assess. Manage 2012, 8, 64-84.

(34) Jardine, T. D.; Kidd, K. A.; Fisk, A. T. Applications, considerations, and sources of uncertainty when using stable isotope analysis in ecotoxicology. Environ. Sci. Technol. 2006, 40, 7501-7511.

(35) Cabana, G.; Rasmussen, J. B. Comparison of aquatic food chains using nitrogen isotopes. Proc. Natl. Acad. Sci. U.S.A. 1996, 93, 1084410847.

(36) Atwell, L.; Hobson, K. A.; Welch, H. E. Biomagnification and bioaccumulation of mercury in an Arctic marine food web: Insights from stable nitrogen isotope analysis. Can. J. Fish. Aquat. Sci. 1998, 55, 11141121.

(37) Jaeger, I.; Hop, H.; Gabrielsen, G. W. Biomagnification of mercury in selected species from an Arctic marine food web in Svalbard. Sci. Total Environ. 2009, 407, 4744-4751.

(38) Jarman, W. M.; Hobson, K. A.; Sydeman, W. J.; Bacon, C. E.; McLaren, E. B. Influence of trophic position and feeding location on contaminant levels in the Gulf of the Farallones food web revealed by stable isotope analysis. Environ. Sci. Technol. 1996, 30, 654-660.

(39) Anderson, O. R. J.; Phillips, R. A.; McDonald, R. A.; Shore, R. F.; McGill, R. A. R.; Bearhop, S. Influence of trophic position and foraging range on mercury levels within a seabird community. Mar. Ecol.: Prog. Ser. 2009, 375, 277-288.

(40) Roxburgh, S. H. Datagrabber (beta) [Computer software]; Retrieved from http://www.steverox.info/software_downloads.htm (accessed January 13, 2012). Canberra, Australia, $200 \overline{6}$.

(41) Ikemoto, T.; Tu, N. P. C.; Okuda, N.; Iwata, A.; Omori, K.; Tanabe, S.; Tuyen, B. C.; Takeuchi, I. Biomagnification of trace elements in the aquatic food web in the Mekong Delta, South Vietnam using stable carbon and nitrogen isotope analysis. Arch. Environ. Contam. Toxicol. 2008, 54, 504-515.

(42) Cossa, D.; Harmelin-Vivien, M.; Mellon-Duval, C.; Loizeau, V.; Averty, B.; Crochet, S.; Chou, L.; Cadiou, J. F. Influences of bioavailability, trophic position, and growth on methylmercury in Hakes (Merluccius merluccius) from Northwestern Mediterranean and Northeastern Atlantic. Environ. Sci. Technol. 2012, 46, 4885-4893.

(43) Pethybridge, H.; Butler, E. C. V.; Cossa, D.; Daley, R; Boudou, A. Trophic structure and biomagnification of mercury in an assemblage of deepwater chondrichthyans from Southeastern Australia. Mar. Ecol.: Prog. Ser. 2012, 451, 163-174.

(44) Dominique, Y.; Maury-Brachet, R.; Muresan, B.; Vigouroux, R.; Richard, S.; Cossa, D.; Mariotti, A.; Boudou, A. Biofilm and mercury availability as key factors for mercury accumulation in fish (Curimata cyprinoides) from a disturbed Amazonian freshwater system. Environ. Toxicol. Chem. 2007, 26, 45-52.

(45) Embury, J. D. Food web structure, mercury biomagnification and carbon pathways in an experimentally flooded wetland. M.Sc. Thesis, University of Manitoba: Winnipeg, Canada, 2000.

(46) Pastershank, G. M. Unifying ecosystem concepts and mercury biomagnification in an estuarine environment using stable isotopes $\left(\delta^{13} \mathrm{C}\right.$ and $\left.\delta^{15} \mathrm{~N}\right)$. Ph.D. Thesis, University of Ottawa: Ottawa, Canada, 2001.

(47) Basnet, S. Trophic transfer of mercury in fish species from Lake Phewa, Pokhara, Nepal. M.Sc. Thesis, Norwegian University of Life Sciences: Aas, Norway, 2011.

(48) Hatton, E. C. The role of invasive Bythotrephes longimanus in lake food webs. M.Sc. Thesis, Queen's University: Kingston, Canada, 2008.

(49) Clayden, M. G.; Kidd, K. A.; Wyn, B.; Kirk, J. L.; Muir, D. C. G.; O'Driscoll, N. J. Mercury biomagnification through food webs is affected by physical and chemical characteristics of lakes. Environ. Sci. Technol. 2013, 47, 12047-12053.

(50) Thera, J. C. Trophic transfer of mercury in a subtropical coastal food web off Southwest Florida. M.Sc. Thesis, Florida Gulf Coast University: Fort Myers, USA, 2011. 
(51) Lavoie, R. A.; Hebert, C. E.; Rail, J. F.; Braune, B.; Yumvihoze, E.; Hill, L. G.; Lean, D. R. S. Trophic structure and mercury distribution in a Gulf of St. Lawrence (Canada) food web using stable isotope analysis. Sci. Total Environ. 2010, 408, 5529-5539.

(52) Vörösmarty, C. J.; McIntyre, P. B.; Gessner, M. O.; Dudgeon, D.; Prusevich, A.; Green, P.; Glidden, S.; Bunn, S. E.; Sullivan, C. A.; Liermann, C. R.; Davies, P. M. Global threats to human water security and river biodiversity. Nature 2010, 467, 555-561.

(53) Carlson, R. E. A trophic state index for lakes. Limnol. Oceanogr. 1977, 22, 361-369.

(54) Quinn, G. P.; Keough, M. J. Experimental Design and Data Analysis for Biologists; Cambridge University Press: Cambridge, U.K., 2002.

(55) R Development Core Team. R: A Language and Environment for Statistical Computing; ISBN 3-900051-07-0, URL http://www.Rproject.org (accessed 16 February 2012), Version 2.13.2; R Foundation for Statistical Computing: Vienna, Austria, 2008.

(56) Evans, M. S.; Lockhart, W. L.; Doetzel, L.; Low, G.; Muir, D.; Kidd, K.; Stephens, G.; Delaronde, J. Elevated mercury concentrations in fish in lakes in the Mackenzie River Basin: The role of physical, chemical, and biological factors. Sci. Total Environ. 2005, 351, 479-500. (57) Jardine, T. D.; Halliday, I. A.; Howley, C.; Sinnamon, V.; Bunn, S. E. Large scale surveys suggest limited mercury availability in tropical north Queensland (Australia). Sci. Total Environ. 2012, 416, 385-393.

(58) Rolfhus, K. R.; Hall, B. D.; Monson, B. A.; Paterson, M. J.; Jeremiason, J. D. Assessment of mercury bioaccumulation within the pelagic food web of lakes in the western Great Lakes region. Ecotoxicology 2011, 20, 1520-1529.

(59) Wyn, B.; Kidd, K. A.; Burgess, N. M.; Curry, R. A. Mercury biomagnification in the food webs of acidic lakes in Kejimkujik National Park and National Historic Site, Nova Scotia. Can. J. Fish. Aquat. Sci. 2009, 66, 1532-1545.

(60) Gantner, N.; Muir, D. C.; Power, M.; Iqaluk, D.; Reist, J. D.; Babaluk, J. A.; Meili, M.; Borg, H.; Hammar, J.; Michaud, W.; Dempson, B.; Solomon, K. R. Mercury concentrations in landlocked arctic charr (Salvelinus alpinus) from the Canadian Arctic. Part II: Influence of lake biotic and abiotic characteristics on geographic trends in 27 populations. Environ. Toxicol. Chem. 2010, 29, 633-643.

(61) Gantner, N.; Power, M.; Iqaluk, D.; Meili, M.; Borg, H.; Sundbom, M.; Solomon, K. R.; Lawson, G.; Muir, D. C. Mercury concentrations in landlocked arctic charr (Salvelinus alpinus) from the Canadian Arctic. Part I: insights from trophic relationships in 18 lakes. Environ. Toxicol. Chem. 2010, 29, 621-632.

(62) Swanson, H. K.; Kidd, K. A. Mercury concentrations in Arctic food fishes reflect the presence of anadromous arctic charr (Salvelinus alpinus), species, and life history. Environ. Sci. Technol. 2010, 44, 32863292.

(63) Chasar, L. C.; Scudder, B. C.; Stewart, A. R.; Bell, A. H.; Aiken, G. R. Mercury cycling in stream ecosystems. 3. Trophic dynamics and methylmercury bioaccumulation. Environ. Sci. Technol. 2009, 43, 27332739.

(64) Hillebrand, H. On the generality of the latitudinal diversity gradient. Am. Nat. 2004, 163, 192-211.

(65) Paine, R. T. Food web complexity and species diversity. Am. Nat. 1966, 100, 65-75.

(66) Kilham, S. S.; Hunte-Brown, M.; Verburg, P.; Pringle, C. M.; Whiles, M. R.; Lips, K. R.; Zandona, E. Challenges for interpreting stable isotope fractionation of carbon and nitrogen in tropical aquatic ecosystems. Verh. Int. Verein. Limnol. 2009, 30, 749-753.

(67) Hallanger, I. G.; Warner, N. A.; Ruus, A.; Evenset, A.; Christensen, G.; Herzke, D.; Gabrielsen, G. W.; Bo̊rga, K. Seasonality in contaminant accumulation in Arctic marine pelagic food webs using trophic magnification factor as a measure of bioaccumulation. Environ. Toxicol. Chem. 2011, 30, 1026-1035.

(68) Wiener, J. G.; Knights, B. C.; Sandheinrich, M. B.; Jeremiason, J. D.; Brigham, M. E.; Engstrom, D. R.; Woodruff, L. G.; Cannon, W. F.; Balogh, S. J. Mercury in soils, lakes, and fish in Voyageurs National Park (Minnesota): Importance of atmospheric deposition and ecosystem factors. Environ. Sci. Technol. 2006, 40, 6261-6268.
(69) Gorski, P. R.; Cleckner, L. B.; Hurley, J. P.; Sierszen, M. E.; Armstrong, D. E. Factors affecting enhanced mercury bioaccumulation in inland lakes of Isle Royale National Park, USA. Sci. Total Environ. 2003, 304, 327-348.

(70) Chételat, J.; Amyot, M.; Garcia, E. Habitat-specific bioaccumulation of methylmercury in invertebrates of small mid-latitude lakes in North America. Environ. Pollut. 2011, 159, 10-17.

(71) Dittman, J. A.; Driscoll, C. T. Factors influencing changes in mercury concentrations in lake water and yellow perch (Percaflavescens) in Adirondack lakes. Biogeochemistry 2009, 93, 179-196.

(72) Bodaly, R. A. D.; Jansen, W. A.; Majewski, A. R.; Fudge, R. J. P.; Strange, N. E.; Derksen, A. J.; Green, D. J. Postimpoundment time course of increased mercury concentrations in fish in hydroelectric reservoirs of northern Manitoba, Canada. Arch. Environ. Contam. Toxicol. 2007, 53, 379-389.

(73) Harris, R. C.; Rudd, J. W. M.; Amyot, M.; Babiarz, C. L.; Beaty, K. G.; Blanchfield, P. J.; Bodaly, R. A.; Branfireun, B. A.; Gilmour, C. C.; Graydon, J. A.; Heyes, A.; Hintelmann, H.; Hurley, J. P.; Kelly, C. A.; Krabbenhoft, D. P.; Lindberg, S. E.; Mason, R. P.; Paterson, M. J.; Podemski, C. L.; Robinson, A.; Sandilands, K. A.; Southworth, G. R.; Louis, V. L. S.; Tate, M. T. Whole-ecosystem study shows rapid fishmercury response to changes in mercury deposition. Proc. Natl. Acad. Sci. U.S.A. 2007, 104, 16586-16591.

(74) Paterson, M. J.; Blanchfield, P. J.; Podemski, C.; Hintelmann, H. H.; Gilmour, C. C.; Harris, R.; Ogrinc, N.; Rudd, J. W. M.; Sandilands, K. A. Bioaccumulation of newly deposited mercury by fish and invertebrates: An enclosure study using stable mercury isotopes. Can. J. Fish. Aquat. Sci. 2006, 63, 2213-2224.

(75) Chen, C. Y.; Stemberger, R. S.; Kamman, N. C.; Mayes, B. M.; Folt, C. L. Patterns of $\mathrm{Hg}$ bioaccumulation and transfer in aquatic food webs across multi-lake studies in the northeast U.S. Ecotoxicology 2005, $14,135-147$

(76) Mackay, D.; Arnot, J. A.; Gobas, F.; Powell, D. E. Mathematical relationships between metrics of chemical bioaccumulation in fish. Environ. Toxicol. Chem. 2013, 32, 1459-1466.

(77) Miskimmin, B. M.; Rudd, J. W. M.; Kelly, C. A. Influence of dissolved organic-carbon, $\mathrm{pH}$, and microbial respiration rates on mercury methylation and demethylation in lake water. Can. J. Fish. Aquat. Sci. 1992, 49, 17-22.

\section{NOTE ADDED AFTER ASAP PUBLICATION}

Table 2 was modified in the version published November 13, 2013. The corrected version published November 21, 2013. 